\title{
GAS EXCHANGES AND PRODUCTION OF COLORED COTTON UNDER SALT SRESS AND NITROGEN FERTILIZATION
}

\author{
TROCAS GASOSAS E PRODUÇÃO DO ALGODOEIRO COLORIDO SOB ESTRESSE \\ SALINO E ADUBAÇÃO NITROGENADA
}

\section{Geovani Soares de LIMA ${ }^{1}$; Adaan Sudário DIAS ${ }^{2}$; Hans Raj GHEYI ${ }^{3}$; Lauriane Almeida dos Anjos SOARES ${ }^{4}$; Reginaldo Gomes NOBRE ${ }^{5}$; Francisco Wesley Alves PINHEIRO ${ }^{6}$; André Alisson Rodrigues da SILVA ${ }^{6}$}

1. Pós-Doutorando em Engenharia Agrícola, PNPD/CAPES, Universidade Federal de Campina Grande-UFCG, Campina Grande, PB, Brasil. geovanisoareslima@gmail.com; 2. Doutorando em Engenharia Agrícola, Programa de Pós graduação em Engenharia Agrícola, UFCG, Campina Grande, PB, Brasil; 3. Professor Visitante Sênior Nacional/CAPES, Universidade Federal do Recôncavo da Bahia, Cruz das Almas, BA, Brasil; 4. Pós-Doutoranda em Engenharia Agrícola, PDJ/CNPq, UFCG, Campina Grande, PB, Brasil; 5. Professor, Doutor, UFCG, Unidade Acadêmica de Ciências Agrárias, Pombal, PB, Brasil; 6. Mestrando em Engenharia Agrícola, Programa de Pós graduação em Engenharia Agrícola, UFCG, Campina Grande, PB, Brasil.

\begin{abstract}
This study was conducted with the objective of evaluating the gas exchanges and production components of colored-fiber cotton as a function of irrigation with water of different saline levels and nitrogen (N) doses. The experiment was carried out in drainage lysimeters, filled with eutrophic Regolithic Neosol of sandy loam texture, in the municipality of Campina Grande-PB, Brazil. The statistical design was randomized blocks and the treatments resulted from the combination of five levels of irrigation water electrical conductivity - ECw $\left(5.1,6.1,7.1,8.1\right.$ and $\left.9.1 \mathrm{dS}^{-1}\right)$ and five $\mathrm{N}$ doses - ND $\left(65 ; 100 ; 135 ; 170 ; 205 \mathrm{mg}\right.$ of $\mathrm{N} \mathrm{kg}^{-1}$ of soil) in a 5 x 5 factorial scheme, with three replicates. The interaction between the saline levels of the irrigation water and the $\mathrm{N}$ doses did not influence significantly any of the analyzed variables. The gas exchanges and production components of the cotton cultivar 'BRS Rubi' were negatively affected by the $\mathrm{ECW}$ higher than $5.1 \mathrm{dS} \mathrm{m}{ }^{-1}$; the $\mathrm{CO}_{2}$ assimilation rate and total number of seeds per plant were the variables most sensitive to the effects of salt stress; $\mathrm{N}$ doses above $65 \mathrm{mg} \mathrm{kg}^{-1}$ led to decrease of stomatal conductance in the cotton crop.
\end{abstract}

KEYWORDS: Gossypium hirsutum L. 'BRS Rubi’. Salinity. Nitrogen

\section{INTRODUCTION}

The herbaceous cotton (Gossypium hirsutum L.) stands out as one of the most important crops for the Brazilian agribusiness, for its volume and value of production, due to the generation of wealth, multiplicity of derivative products, utilization of its seeds in animal feed, in the form of cake, or in the production of edible oil of high added value, inserted in the group of bioenergetic products (JERÔNIMO et al., 2014).

In Northeast Brazil, especially in semi-arid zones, cotton production is one of the agricultural activities of small- and medium-sized producers, due to its great economic and social potential (CAVALCANTE et al., 2015). In this region, the occurrence of long drought periods and the irregularities of rainfalls make the practice of irrigation indispensable (LIMA et al., 2014). In addition, the water sources available for irrigation in this region change according to the period of the year and in geographic terms, and the occurrence of water sources with high concentration of salts is common (BEZERRA et al., 2010).
Irrigation using water with high contents of salts affects the biochemical, physiological and morphological processes of the plants, because it reduces the osmotic potential of the soil solution, restricting the availability of water and/or due to the excessive accumulation of ions in plant tissues, which can cause ionic toxicity, nutritional imbalance, or both (NEVES et al., 2009). However, these effects also depend on other factors, such as species, cultivar, phenological stage, types of salts, duration of salt stress, irrigation management and edaphoclimatic conditions (MUNNS; TESTER, 2008).

Among the alternatives that can minimize the deleterious effects caused by high concentrations of salts on the plants, nitrogen $(\mathrm{N})$ fertilization stands out (LIMA et al., 2014). This dependence occurs due to the vital functions of $\mathrm{N}$ in the plant, being constituent of proteins, enzymes, coenzymes, nucleic acids, phytochromes and chlorophyll, besides affecting the rates of leaf initiation and expansion (BARHOUMI et al., 2010). Additionally, this macronutrient can increase the capacity of osmotic adjustment of the plants to salinity (SILVA et al., 2008). 
Although cotton is considered as a crop tolerant to salinity (AYERS; WESTCOT, 1999), there are few studies conducted and those that exist diverge with respect to the degree of tolerance of cultivars of cotton with naturally colored fibers. Thus, considering the possibility of varietal differences, it is of great importance to conduct studies that evaluate the interaction between water salinity and $\mathrm{N}$ doses in the colored-fiber cotton.

In this context, this study was conducted in order to evaluate gas exchanges and production components of the colored-fiber cotton, cv. 'BRS Rubi', as a function of irrigation with saline water and $\mathrm{N}$ doses.

\section{MATERIAL AND METHODS}

The experiment was carried out in drainage lysimeters under greenhouse conditions, at the Center of Technology and Natural Resources of the Federal University of Campina Grande (CTRN/UFCG), located in the municipality of Campina Grande-PB, Brazil, at the geographic coordinates of $7^{\circ} 15^{\prime} 18^{\prime \prime} \mathrm{S}, 35^{\circ} 52^{\prime} 28^{\prime \prime} \mathrm{W}$ and mean altitude of $550 \mathrm{~m}$.

The experimental design was randomized blocks, in a $5 \times 5$ factorial scheme, with three replicates, and the treatments resulted from the combination of five levels of electrical conductivity of the irrigation water - $\mathrm{ECw}(5.1,6.1,7.1,8.1$ and $\left.9.1 \mathrm{dS} \mathrm{m}^{-1}\right)$ and five $\mathrm{N}$ doses - ND $(65 ; 100 ; 135$; $170 ; 205 \mathrm{mg}$ of $\mathrm{N} \mathrm{kg}^{-1}$ of soil), considering the recommendation of $\mathrm{N}$ fertilization $\left(100 \mathrm{mg}\right.$ of $\mathrm{N} \mathrm{kg}^{-}$ ${ }^{1}$ of soil) of Novais et al. (1991) for pot experiments. The lowest ECw level used in this study correspond to the threshold salinity for the crop, according to Ayers \& Westcot (1999).

The experiment used 20-L drainage lysimeters (height of $35 \mathrm{~cm}$, bottom diameter of 20 $\mathrm{cm}$ and upper opening of $31 \mathrm{~cm}$ ) perforated at the bottom to allow drainage and connected to a 4-mmdiameter drain. The tip of the drain inside the lysimeter was involved with a nonwoven geotextile (Bidim OP 30) to avoid obstruction by soil material and, below each drain, a plastic bottle was placed to collect the drained water and allowed determination of water consumed by the plant.

The lysimeters were filled with a $0.5-\mathrm{kg}$ layer of crushed stone, followed by $26 \mathrm{~kg}$ of a eutrophic Regolithic Neosol of sandy loam texture (layer of $0-20 \mathrm{~cm}$ ), which had been properly pounded to break up clods, collected from the rural area of the municipality of Esperança-PB, whose chemical and physical attributes (Table 1) were determined according to the methodology proposed by Claessen (1997).

Table 1.Chemical and physical characteristicsof the eutrophic Regolithic Neosol used in the experiment.

\begin{tabular}{|c|c|c|c|c|c|c|c|c|}
\hline \multicolumn{9}{|c|}{ Chemical characteristics } \\
\hline \multirow[t]{2}{*}{$\mathrm{pH}_{\mathrm{ps}}$} & \multirow{2}{*}{$\begin{array}{c}\text { O.M } \\
\left(\text { dag kg }^{-1}\right)\end{array}$} & \multirow{2}{*}{$\begin{array}{c}\mathrm{P} \\
\left(\mathrm{mg} \mathrm{kg}^{-1}\right)\end{array}$} & $\mathrm{K}^{+}$ & $\mathrm{Na}^{+}$ & $\mathrm{Ca}^{2+}$ & $\mathrm{Mg}^{2+}$ & $\mathrm{Al}^{3+}$ & $\mathrm{H}^{+}$ \\
\hline & & & \multicolumn{6}{|c|}{$\ldots \ldots \ldots .\left(\mathrm{cmol}_{\mathrm{c}} \mathrm{kg}^{-1}\right) \ldots$} \\
\hline 5.63 & 1.83 & 18.2 & 0.21 & 0.17 & 3.49 & 2.99 & 0.00 & 5.81 \\
\hline \multicolumn{9}{|c|}{ Physical characteristics } \\
\hline \multicolumn{3}{|c|}{ Size fraction $\left(\mathrm{g} \mathrm{kg}^{-1}\right)$} & \multirow{2}{*}{$\begin{array}{c}\text { Textural } \\
\text { class }\end{array}$} & \multicolumn{2}{|c|}{ Water content $(\mathrm{kPa})$} & \multirow[t]{2}{*}{ AW } & \multirow{2}{*}{$\begin{array}{l}\text { Total } \\
\text { porosity } \\
\mathrm{m}^{3} \mathrm{~m}^{-3}\end{array}$} & \multirow{2}{*}{$\begin{array}{c}\mathrm{AD} \\
\left(\mathrm{kg} \mathrm{dm}^{-3}\right)\end{array}$} \\
\hline Sand & Silt & Clay & & $\begin{array}{r}33.42 \\
\ldots \ldots \ldots \ldots .\end{array}$ & $\begin{array}{c}1519.5 \\
\text { dag kg }^{-1}\end{array}$ & & & \\
\hline 572.3 & 100.8 & 326.9 & SL & 12.68 & 4.98 & 7.70 & 0.57 & 1.13 \\
\hline
\end{tabular}

O.M. - Organic matter: Walkley-Black wet digestion; $\mathrm{Ca}^{2+}$ and $\mathrm{Mg}^{2+}$ extracted with $1 \mathrm{~mol} \mathrm{~L}^{-1} \mathrm{KCl}$ at $\mathrm{pH} 7.0$; $\mathrm{Na}^{+}$and $\mathrm{K}^{+}$extracted with 1 mol L ${ }^{-1} \mathrm{NH}_{4} \mathrm{OAc}$ at $\mathrm{pH}$ 7.0; ECse - Electrical conductivity of the saturation extract; SL - Sandy loam; AW - Available water; AD Apparent density.

The present study evaluated the cotton cultivar 'BRS Rubi', because it is a genetic material indicated for the cultivation in the semi-arid region of Northeast Brazil. It is a cultivar with dark brown or reddish brown fiber, mean height of $1.10 \mathrm{~m}$ and cycle of 120 to 140 days. It has yield between 1,539 and $1,894 \mathrm{~kg} \mathrm{ha}^{-1}$, under rainfed conditions, in the Northeast region (EMBRAPA,2011).

The irrigation waters were prepared using the salts $\mathrm{NaCl}, \mathrm{CaCl}_{2} \cdot 2 \mathrm{H}_{2} \mathrm{O}$ and $\mathrm{MgCl}_{2} \cdot 6 \mathrm{H}_{2} \mathrm{O}$, maintaining a proportion equivalent to $7: 2: 1$ between $\mathrm{Na}^{+}, \mathrm{Ca}^{2+}$ and $\mathrm{Mg}^{2+}$, respectively, adjusting the concentration of the public-supply water available in the municipality of Campina Grande$\mathrm{PB}$, considering the relationship between $\mathrm{ECw}$ and the concentration of salts $\left(10^{*} \mathrm{mmol}_{\mathrm{c}} \mathrm{L}^{-1}=\mathrm{ECw} \mathrm{dS}\right.$ $\mathrm{m}^{-1}$ ), according to Richards (1954).

Before sowing, soil moisture was increased to container capacity using the respective saline waters, according to each treatment. After sowing, irrigation was daily performed by applying in each lysimeter the water volume to maintain the soil 
close to container capacity. The applied volume was determined based on the water demand of the plants, estimated through the water balance: applied water volume minus the volume drained in the previous irrigation.

Eight seeds of the cotton cultivar 'BRS Rubi' were planted in each lysimeter, at depth of 3.0 $\mathrm{cm}$, equidistantly distributed. Thinning was performed at 15 and 25 days after sowing (DAS), to leave only one plant per lysimeter.

Phosphorus and potassium fertilizations were applied based on the recommendation of Novais et al. (1991), by applying the equivalent to $300 \mathrm{mg}$ of $\mathrm{P}_{2} \mathrm{O}_{5}$ and $150 \mathrm{mg}$ of $\mathrm{K}_{2} \mathrm{O} \mathrm{kg}^{-1}$ of soil, using single superphosphate and potassium chloride. Urea was used as N source. Phosphorus was totally applied as basal dose. Potassium fertilizations and the different $\mathrm{N}$ doses were equally split, at 12,28 and 42 and at 15, 30, 45 and 60 DAS, respectively.

Micronutrients were applied via foliar fertilizations, at 25, 40 and $55 \mathrm{DAS}$, applying $3 \mathrm{~L}$ of solution containing $2.5 \mathrm{~g} \mathrm{~L}^{-1}$ of Ubyfol [(N (15\%); $\mathrm{P}_{2} \mathrm{O}_{5}(15 \%) ; \mathrm{K}_{2} \mathrm{O}$ (15\%); $\mathrm{Ca}(1 \%) ; \mathrm{Mg}(1.4 \%) ; \mathrm{S}$ (2.7\%); Zn (0.5\%); B (0.05\%); Fe (0.5\%); Mn $(0.05 \%) ; \mathrm{Cu}(0.5 \%)$; Mo (0.02\%)]. Phytosanitary control was performed preventively through the application of insecticides from the Neonicotinoid chemical group, fungicide from the triazole chemical group and acaricide from the abamectin chemical group.

The effects of the different saline levels of the irrigation water and $\mathrm{N}$ doses on the cotton cv. 'BRS Rubi' were evaluated at 60 DAS, based on the determination of gas exchanges, measured through stomatal conductance $(g s)$, transpiration $(E), \mathrm{CO}_{2}$ assimilation rate $(A)$, internal $\mathrm{CO}_{2}$ concentration (Ci), instantaneous carboxylation efficiency (EICI), instantaneous water use efficiency (WUE). The production components determined at harvest consisted of total number of seeds (TNS), mean boll weight (MBW) and fiber yield (FY) per plant.

Stomatal conductance (mol of $\mathrm{H}_{2} \mathrm{O} \mathrm{m}^{-2} \mathrm{~s}^{-1}$ ), transpiration (mmol of $\left.\mathrm{H}_{2} \mathrm{O} \quad \mathrm{m}^{-2} \mathrm{~s}^{-1}\right), \mathrm{CO}_{2}$ assimilation rate $\left(\mu \mathrm{mol} \mathrm{m} \mathrm{m}^{-2} \mathrm{~s}^{-1}\right)$ and internal $\mathrm{CO}_{2}$ concentration $\left(\mu \mathrm{mol} \mathrm{m} \mathrm{m}^{-2} \mathrm{~s}^{-1}\right)$ were measured on the third leaf counted from the apex, using the portable photosynthesis meter "LCPro+" from ADC BioScientific Ltda. These data were used to evaluate the instantaneous carboxylation efficiency $(\mathrm{A} / \mathrm{Ci})$ $\left.\left[\left(\mu \mathrm{mol} \mathrm{m} \mathrm{m}^{-2} \mathrm{~s}^{-1}\right)(\mu \mathrm{mol} \mathrm{mol})^{-1}\right)^{-1}\right]$ and instantaneous water use efficiency (WUE) (A/E) $\left[\left(\mu \mathrm{mol} \mathrm{m} \mathrm{m}^{-2} \mathrm{~s}^{-1}\right)\right.$ $\left(\mathrm{mol} \mathrm{H} \mathrm{O} \mathrm{m}^{-2} \mathrm{~s}^{-1}\right)^{-1}$ ].

Bolls were manually harvested when $90 \%$ of the fruits were open. After this step, the bolls of each plot were weighed and the lint was manually removed to separate fiber from the seeds. Total number of seeds was obtained after counting the seeds, whereas mean boll weight was determined after removing the seeds, using a scale with precision of $0.01 \mathrm{~g}$. Fiber yield was measured considering the methodology described by Albrecht et al. (2009), according to Eq 2:

$$
\text { FV }(\%)=\frac{F M}{\text { TM }} \times 100
$$

where:

$\mathrm{FY}=$ Fiber yield $(\%)$,

$\mathrm{FM}=$ Fiber mass $\left(\mathrm{g}_{\text {plant }}{ }^{-1}\right)$;

$\mathrm{TM}=$ Total mass of seed cotton $\left(\mathrm{g}\right.$ plant $\left.{ }^{-1}\right)$.

The obtained data were evaluated through analysis of variance by $F$ test at 0.05 and 0.01 probability levels and, in cases of significance, linear and quadratic polynomial regression analyses were applied, using the statistical software SISVAR-ESAL (FERREIRA, 2011).

\section{RESULTS AND DISCUSSION}

According to the summary of the analysis of variance (Table 2), the different saline levels of the irrigation water (SL) promoted significant increases in all variables of gas exchanges $(g s, E, A, C i$, EICI and WUE) of the cotton crop, cv. 'BRS Rubi'. However, the studied $\mathrm{N}$ doses significantly influenced only the $\mathrm{CO}_{2}$ assimilation rate, while the interaction between factors (SL x ND) did not affect any variable significantly.

The stomatal conductance was significantly affected $(\mathrm{p}<0.01)$ by the increase in ECw levels and, according to the regression equation (Figure 1A), the data adjusted best to the quadratic model and the highest $\left(0.33 \mathrm{~mol}\right.$ of $\left.\mathrm{H}_{2} \mathrm{O} \mathrm{m}^{-2} \mathrm{~s}^{-1}\right)$ and lowest $(0.12$ mol of $\left.\mathrm{H}_{2} \mathrm{O} \mathrm{m}^{-2} \mathrm{~s}^{-1}\right)$ values of $g s$ were obtained in plants subjected to $\mathrm{ECw}$ of 5.1 and $9.1 \mathrm{dS} \mathrm{m}^{-1}$, respectively. Comparing the stomatal conductance of plants subjected to the lowest and highest saline levels, there was a decrease of $0.21 \mathrm{~mol}$ of $\mathrm{H}_{2} \mathrm{O} \mathrm{m}^{-2}$ $\mathrm{s}^{-1}$, which corresponded to a reduction of $63.63 \%$ in relation to the control.

This reduction observed in $g s$ (Figure 1A) is partially related to the decrease in the osmotic potential of the soil solution, caused by the excess of soluble salts in the root zone, and to the ionic effect, caused by the accumulation of ions in the plant tissues (MUNNS; TESTER, 2008). When it occurs, gs limits the inflow of $\mathrm{CO}_{2}$ to the leaves (DALLAGNOL et al., 2011) and, consequently, there is a reduction in the $\mathrm{CO}_{2}$ assimilation rate, through the decrease in the $\mathrm{CO}_{2}$ partial pressure in the intercellular spaces (SHIMAZAKI; YAMAGUCHI-SHINOZAKI, 2007). 
Table 2. Summary of the analysis of variance for stomatal conductance ( $g s)$, transpiration $(E), \mathrm{CO}_{2}$ assimilation rate $(A)$, internal $\mathrm{CO}_{2}$ concentration $(\mathrm{Ci})$, instantaneous carboxylation efficiency (EICI) and instantaneous water use efficiency (WUE) of cotton plants, cv. 'BRS Rubi', irrigated with waters of different saline levels and nitrogen doses, at 60 days after sowing.

\begin{tabular}{llllllll}
\hline \multirow{2}{*}{ Source of variation } & \multirow{2}{*}{ DF } & \multicolumn{7}{c}{ Mean squares } \\
\cline { 3 - 8 } & & $g s$ & $E$ & $A$ & $C i$ & EICI & WUE \\
\hline Saline levels (SL) & 4 & $0.21^{* *}$ & $2.01^{* *}$ & $88.46^{* *}$ & $20070.46^{* *}$ & $0.001^{* *}$ & $5.23^{*}$ \\
$\quad$ Linear regression & 1 & $0.39^{* *}$ & $7.58^{* *}$ & $324.53^{* *}$ & $66630.94^{* *}$ & $0.005^{* *}$ & $14.32^{*}$ \\
Quadratic regression & 1 & $0.05^{*}$ & $0.01^{\mathrm{ns}}$ & $15.89^{*}$ & $1144.56^{\mathrm{ns}}$ & $0.0005^{*}$ & $4.75^{*}$ \\
N doses (ND) & 4 & $0.07^{* *}$ & $0.28^{\mathrm{ns}}$ & $3.86^{\mathrm{ns}}$ & $1732.51^{\mathrm{ns}}$ & $0.001^{\mathrm{ns}}$ & $0.27^{\mathrm{ns}}$ \\
$\quad$ Linear regression & 1 & $0.17^{* *}$ & $0.08^{\mathrm{ns}}$ & $11.15^{\mathrm{ns}}$ & $1865.60^{\mathrm{ns}}$ & $0.0002^{\mathrm{ns}}$ & $0.16^{\mathrm{ns}}$ \\
Quadratic regression & 1 & $0.10^{* *}$ & $0.10^{\mathrm{ns}}$ & $0.60^{\mathrm{ns}}$ & 3831.47 & $0.00001^{\mathrm{ns}}$ & $0.58^{\mathrm{ns}}$ \\
Interaction (SL x ND) & 16 & $0.02^{\mathrm{ns}}$ & $0.35^{\mathrm{ns}}$ & $10.38^{\mathrm{ns}}$ & $4297.94^{\mathrm{ns}}$ & $0.0002^{\mathrm{ns}}$ & $1.85^{\mathrm{ns}}$ \\
Blocks & 2 & $0.006^{\mathrm{ns}}$ & $0.47^{\mathrm{ns}}$ & $4.15^{\mathrm{ns}}$ & $1339.45^{\mathrm{ns}}$ & $0.0001^{\mathrm{ns}}$ & $3.12^{\mathrm{ns}}$ \\
Residual & 48 & 0.004 & 7.29 & 4.30 & 2484.32 & 0.00008 & 2.32 \\
\hline CV $(\%)$ & 15.28 & 24.00 & 12.57 & 14.91 & 12.87 & 17.15 \\
\hline ns, **, * respectively, not significant, significant at $\mathrm{p}<0.01$ and $\mathrm{p}<0.05$. & & &
\end{tabular}
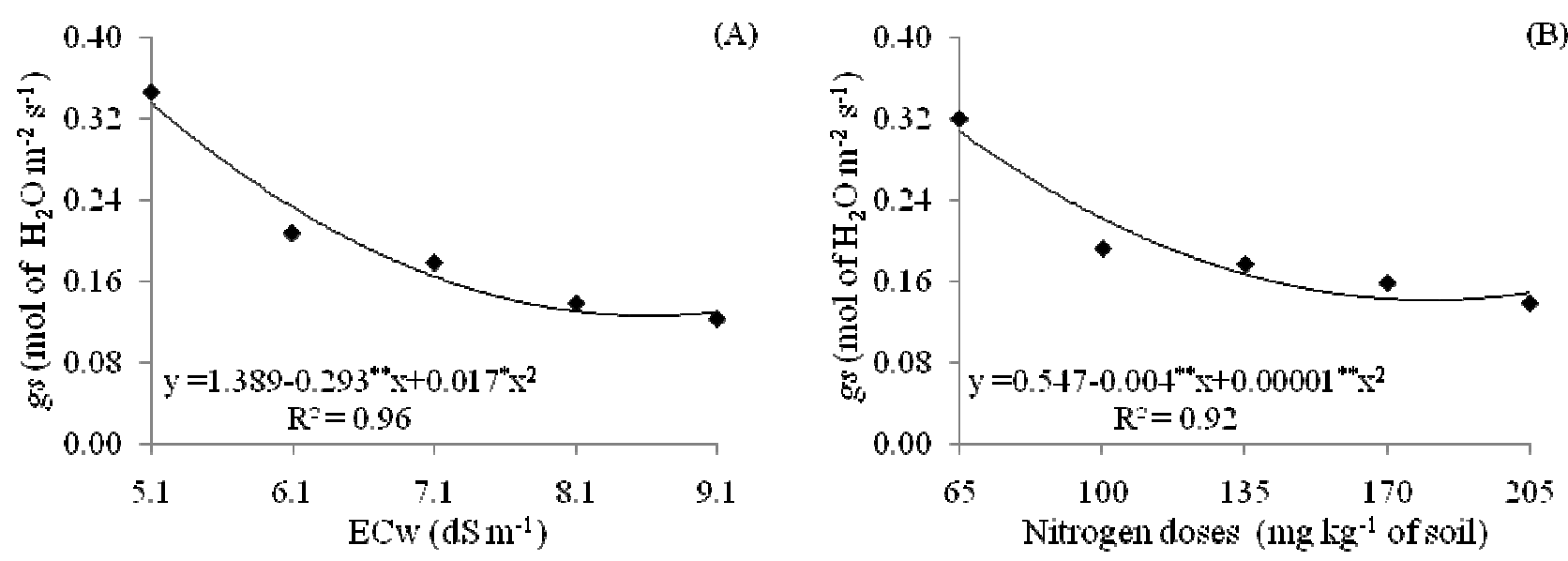

Figure 1. Stomatal conductance - $g s$ of cotton, cv. 'BRS Rubi', as a function of the electrical conductivity of the irrigation water - ECW (A) and nitrogen doses (B), at 60 days after sowing.

The stomatal conductance of 'BRS Rubi' cotton was also negatively affected $(\mathrm{p}<0.01)$ by the fertilization with $\mathrm{N}$ doses and, based on the regression equation (Figure 1B), its maximum value $\left(0.329 \mathrm{~mol}\right.$ of $\left.\mathrm{H}_{2} \mathrm{O} \mathrm{m}^{-2} \mathrm{~s}^{-1}\right)$ was obtained in plants subjected to $\mathrm{N}$ dose of $65 \mathrm{mg} \mathrm{kg}^{-1}$ of soil; from this point on, there was a sharp reduction and the lowest $g s$ value $\left(0.147 \mathrm{~mol}\right.$ of $\left.\mathrm{H}_{2} \mathrm{O} \mathrm{m}^{-2} \mathrm{~s}^{-1}\right)$ was obtained in plants fertilized with $205 \mathrm{mg} \mathrm{kg}^{-1}$ of soil, i.e., there was a decrease of $0.18 \mathrm{~mol}$ of $\mathrm{H}_{2} \mathrm{O} \mathrm{m}^{-2} \mathrm{~s}^{-1}$ between the lowest and highest $\mathrm{N}$ doses, characterizing the closure of the stomata of the cotton crop.

This may have been a consequence of the release of malate from the guard cells, causing the efflux of $\mathrm{K}^{+}$and, consequently, stomatal closure (SHIMAZAKI et al., 2007), promoting an increment in the resistance to $\mathrm{CO}_{2}$ diffusion. Melo et al.
(2009), evaluating the effects of $\mathrm{N}$ and $\mathrm{K}$ levels, by fertigation, on the physiological characteristics of banana, cultivar 'Prata-Anã', also observed that the excess of $\mathrm{N}$ caused negative effects on stomatal conductance.

The transpiration of 'BRS Rubi' cotton significantly $(\mathrm{p}<0.01)$ decreased with the increment in the saline levels of the irrigation water and the regression equation (Figure 2A) showed linear reduction of $7.08 \%$ per unit increase in $\mathrm{ECW}$. Comparing the transpiration of plants irrigated with ECw of $5.1 \mathrm{dS} \mathrm{m}^{-1}$ in relation to those subjected to $\mathrm{ECw}$ of $9.1 \mathrm{dS} \mathrm{m}^{-1}$, there was a decrease of $44.34 \%$ in $E\left(0.90 \mathrm{mmol}\right.$ of $\left.\mathrm{H}_{2} \mathrm{O} \mathrm{m}^{-2} \mathrm{~s}^{-1}\right)$. This reduction in transpiration caused by the increase in $\mathrm{ECW}$ was probably due to the stomatal limitation (Figure 1A), which is a defense strategy of the plant to minimize 
the excessive dehydration or a consequence of the water imbalance in the epidermis of the leaves, because $E$ is closely related to stomatal opening, since they offer resistance to water diffusion from inside the leaf to the atmosphere (RIBEIRO et al., 2009) and, consequently, it becomes a limiting factor for $\mathrm{CO}_{2}$ assimilation rate (Figure 2B). Lima et al. (2015), evaluating the water relations and gas exchanges of castor bean under salinity and cationic nature of the irrigation water ( $\mathrm{ECw}$ from 0.6 to 4.5 $\mathrm{dS} \mathrm{m}{ }^{-1}$ ), also observed that the $E$ of castor bean, cv. 'BRS Energia', was negatively affected by the increment in ECw.
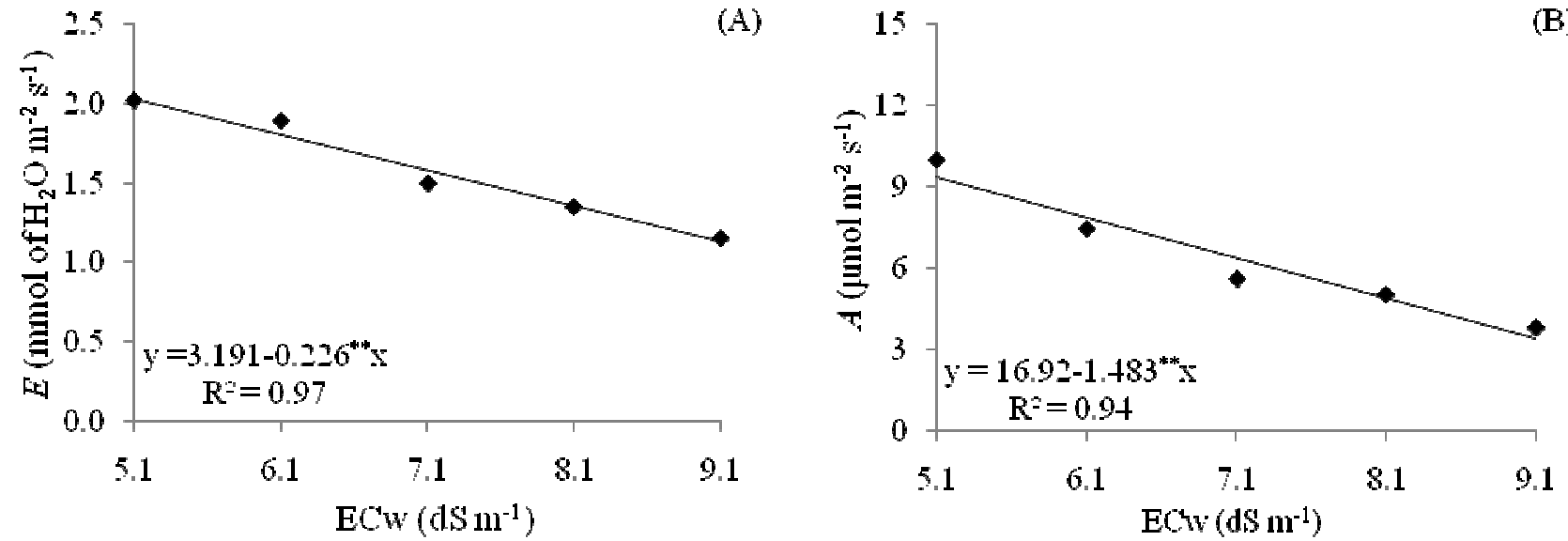

Figure 2. Transpiration $-E$ (A) and $\mathrm{CO}_{2}$ assimilation rate $-A$ of cotton, cv. 'BRS Rubi', as a function of the electrical conductivity of the irrigation water - ECw, at 60 days after sowing.

The $\mathrm{CO}_{2}$ assimilation rate of 'BRS Rubi' cotton decreased $(\mathrm{p}<0.01)$ linearly with the increment in the saline levels of the irrigation water. According to the regression model (Figure 2B), as observed for $g s$ (Figure 1A) and $E$ (Figure 2A), the highest capacity of $\mathrm{CO}_{2}$ assimilation $\left(9.35 \mu \mathrm{mol} \mathrm{m}{ }^{-2}\right.$ $\mathrm{s}^{-1}$ ) was found in cotton plants irrigated with ECw of $5.1 \mathrm{dS} \mathrm{m}^{-1}$. However, plants subjected to the highest saline level $\left(9.1 \mathrm{dS} \mathrm{m}^{-1}\right)$ exhibited a substantial reduction in this variable, with minimum value of $3.42 \mu \mathrm{mol} \mathrm{m} \mathrm{m}^{-2}$, resulting in a decrease of $63.39 \%$ in $\mathrm{CO}_{2}$ assimilation rate, in relation to plants irrigated with the threshold saline level for the crop $\left(5.1 \mathrm{dS} \mathrm{m}^{-1}\right)$.

The sharp reduction in $\mathrm{CO}_{2}$ assimilation rate is possibly a reflex of the decrease in gs (Figure 1A) and in transpiration (Figure 2A) and the increase in the internal $\mathrm{CO}_{2}$ concentration (Figure 3A), demonstrating low use efficiency of the $\mathrm{CO}_{2}$ that entered the cell, which may have been promoted by the lower $\mathrm{CO}_{2}$ inflow in the substomatal chamber to perform photosynthesis (TAIZ; ZEIGER, 2009). Reduction in $\mathrm{CO}_{2}$ assimilation rate has also been reported in jatropha (SOUSA et al., 2012) and castor bean (LIMA et al., 2014).

Contrary to results for $g s$ (Figure 1A), $E$ (Figure 2A) and $A$ (Figure 2B), the increasing levels of $\mathrm{ECw}$ have an increasing and linear effect on the internal $\mathrm{CO}_{2}$ concentration of 'BRS Rubi' cotton, and the regression equation (Figure 3A) demonstrates an increment in $C i$ of $11.59 \%$ per unit increase in $\mathrm{ECw}$, i.e., plants irrigated with water of high salinity $\left(9.1 \mathrm{dS} \mathrm{m}^{-1}\right)$ showed an increment in $C i$ of $85 \mu \mathrm{mol} \mathrm{m} \mathrm{m}^{-2} \mathrm{~s}^{-1}$ in relation to those irrigated with water of $5.1 \mathrm{dS} \mathrm{m}^{-1}$. This increase in $C i$ may be related to the low values of water potential in the leaf, which occur due to the reduction in gs (Figure $1 \mathrm{~A})$, caused by the decrease in the osmotic potential of the solution, besides the reduction in the activity of enzymes involved in the process of $\mathrm{CO}_{2}$ fixation, because under salt stress conditions the increase in $\mathrm{CO}_{2}$ indicates that it is not being used for the synthesis of sugars during the photosynthesis, with consequent accumulation of this gas, suggesting the interference of a non-stomatal factor in this process, which may result in damages to the photosynthetic apparatus of the plants (FREIRE et al., 2014).

Maintaining the same trend observed for $g s$ (Figure 1A) and $A$ (Figure 2B), the saline levels of the irrigation water also negatively interfered $(\mathrm{p}<0.01)$ with the instantaneous carboxylation efficiency of 'BRS Rubi' cotton. Based on the regression equation, the effects of the different saline levels were more accentuated on plants irrigated using water with ECw of $9.1 \mathrm{dS} \mathrm{m}^{-1}$ and the highest EICI of $0.037\left[\left(\mu \mathrm{mol} \mathrm{m} \mathrm{s}^{-1}\right)\left(\mu \mathrm{mol} \mathrm{mol}{ }^{-}\right.\right.$ $\left.{ }^{1}\right)^{-1}$ ] was obtained at ECw of $5.1 \mathrm{dS} \mathrm{m}^{-1}$ (Figure 3B), with later reduction from this point on until the minimum value of $0.010\left[\left(\mu \mathrm{mol} \mathrm{m} \mathrm{m}^{-2}\right)\left(\mu \mathrm{mol} \mathrm{mol}^{-}\right.\right.$ $\left.{ }^{1}\right)^{-1}$ ] in plants irrigated with ECw of $9.1 \mathrm{dS} \mathrm{m}^{-1}$, i.e., 
there was a reduction of $72.97 \%$ in the EICI of plants under ECw of $9.1 \mathrm{dS} \mathrm{m}^{-1}$ in comparison to the lowest saline level $\left(5.1 \mathrm{dS} \mathrm{m}^{-1}\right)$.

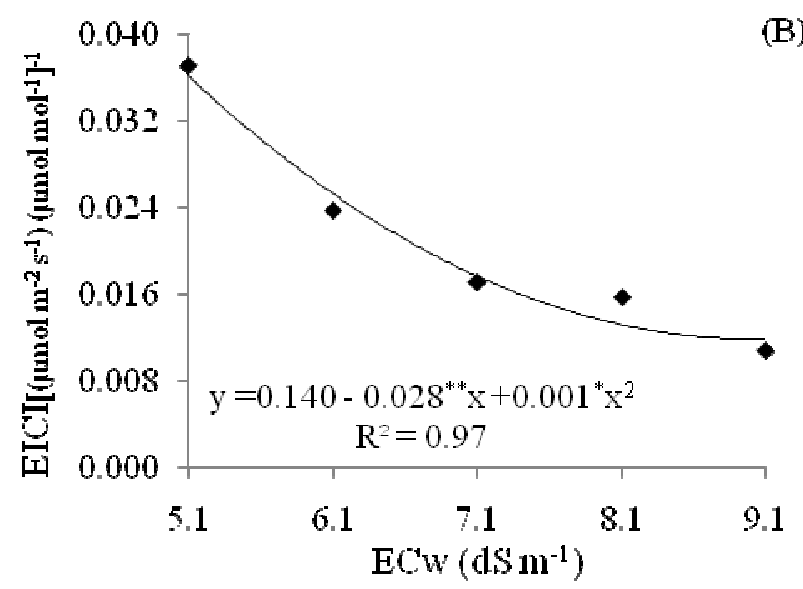

(C)

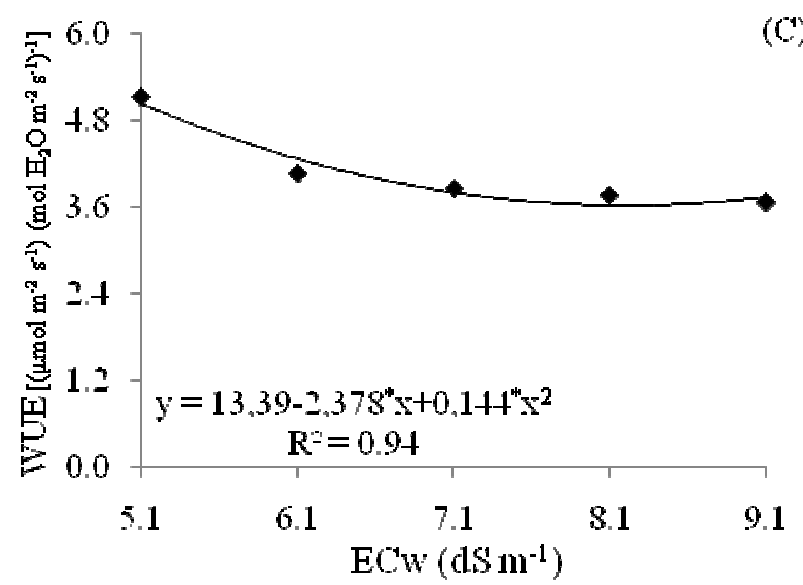

Figure 3. Internal $\mathrm{CO}_{2}$ concentration - $C i$ (A), instantaneous carboxylation efficiency -EICI (B) and instantaneous water use efficiency - WUE (C) of cotton, cv. 'BRS Rubi', as a function of the electrical conductivity of the irrigation water $-\mathrm{ECw}$, at 60 days after sowing.

The expressive reduction in EICI observed in cotton plants, cv. 'BRS Rubi', subjected to high $\mathrm{ECW}$ levels, suggests that it is probably a reflex of the low rates of $\mathrm{CO}_{2}$ assimilation (Figure 2B), in relation to the $\mathrm{CO}_{2}$ found in the substomatal chamber (Figure 3A), because, if the internal $\mathrm{CO}_{2}$ concentration increases and there is a decrease in $\mathrm{CO}_{2}$ consumption in the chloroplasts, due to the reduction in photosynthetic activity, the EICI ratio will also be reduced (SILVA et al., 2015). In addition, the entry of $\mathrm{CO}_{2}$ into the leaf mesophyll may have decreased due to the reduction in $g s$, but the consumption of $\mathrm{CO}_{2}$ in the chloroplast may have been reduced as well (SUASSUNA et al., 2014).

Similar to EICI (Figure 3B), the instantaneous water use efficiency of 'BRS Rubi' cotton was also significantly $(\mathrm{p}<0.05)$ influenced by the irrigation with increasing $\mathrm{ECw}$ levels and the data fitted best to the quadratic model (Figure 3C). As the $\mathrm{ECW}$ levels increased, there was a reduction in WUE, which reached maximum value of 5.12 $\left[\left(\mu \mathrm{mol} \mathrm{m} \mathrm{m}^{-2} \mathrm{~s}^{-1}\right) \quad\left(\mathrm{mol} \mathrm{H}_{2} \mathrm{O} \mathrm{m}^{-2} \mathrm{~s}^{-1}\right)^{-1}\right]$ in plants cultivated under irrigation with $5.1 \mathrm{dS} \mathrm{m}^{-1}$ and minimum of $3.66\left[\left(\mu \mathrm{mol} \mathrm{m} \mathrm{s}^{-1}\right)\left(\mathrm{mol} \mathrm{H}_{2} \mathrm{O} \mathrm{m}^{-2} \mathrm{~s}^{-1}\right)^{-1}\right]$ in plants under ECw of $9.1 \mathrm{dS} \mathrm{m}^{-1}$. In other words, there was a reduction in WUE of $1.46\left[\left(\mu \mathrm{mol} \mathrm{m} \mathrm{m}^{-2} \mathrm{~s}^{-}\right.\right.$ 1) $\left.\left(\mathrm{mol} \mathrm{H}_{2} \mathrm{O} \mathrm{m}^{-2} \mathrm{~s}^{-1}\right)^{-1}\right]$ in plants irrigated with $\mathrm{ECW}$ of $9.1 \mathrm{dS} \mathrm{m}^{-1}$ in relation to those under $5.1 \mathrm{dS} \mathrm{m}^{-1}$.

This decrease in instantaneous water use efficiency observed in plants cultivated under $\mathrm{ECW}$ of $6.1,7.1,8.1$ and $9.1 \mathrm{dS} \mathrm{m}^{-1}$ can be related to the alteration in the $\mathrm{CO}_{2}$ assimilation rates and leaf transpiration, which possibly occurred due to the low water availability in the soil causing stomatal closure (Figure 1A) and, consequently, reduced leaf transpiration (Figure 2A) and $\mathrm{CO}_{2}$ assimilation rate (Figure 2B), directly affecting WUE (WILLADINO; CAMARA, 2004).

According to the summary of the analysis of variance (Table 3 ), there was significant effect of the saline levels of the irrigation water on the total number of seeds (TNS), mean boll weight (MBW) 
and fiber yield (FY). Regarding the $\mathrm{N}$ doses, and the interaction between the studied factors (SL x ND), there was no significant effect on any of the evaluated variables.

Table 3. Summary of the analysis of variance for total number of seeds (TNS), mean boll weight (MBW) and fiber yield (FY) per plant of cotton, cv. 'BRS Rubi', irrigated with waters of different saline levels and nitrogen doses, at 130 days after sowing.

\begin{tabular}{ccccc}
\hline \multirow{2}{*}{ Source of variation } & \multirow{2}{*}{ DF } & \multicolumn{3}{c}{ Mean squares } \\
\cline { 3 - 5 } & 4 & TNS & MBW & FY \\
\hline Saline levels (SL) & 1 & $33650.72^{* *}$ & $1.68^{*}$ & $467.49^{* *}$ \\
Linear regression & 1 & $3511.32^{* *}$ & $4.77^{* *}$ & $1570.34^{* *}$ \\
Quadratic regression & 1 & $226.16^{\mathrm{ns}}$ & $0.34^{\mathrm{ns}}$ & $177.96^{\mathrm{ns}}$ \\
N doses (ND) & 4 & $0.31^{\mathrm{ns}}$ & $99.37^{\mathrm{ns}}$ \\
Interaction (SL x ND) & 16 & $606.12^{\mathrm{ns}}$ & $0.43^{\mathrm{ns}}$ & $79.08^{\mathrm{ns}}$ \\
Blocks & 2 & $33.37^{\mathrm{ns}}$ & $0.15^{\mathrm{ns}}$ & $32.02^{\text {ns }}$ \\
Residual & 48 & 138.11 & 0.32 & 62.58 \\
CV $(\%)$ & & 13.45 & 17.97 & 20.44 \\
\hline
\end{tabular}

$\mathrm{ns}, * *, *$ respectively, not significant, significant at $\mathrm{p}<0.01$ and $\mathrm{p}<0.05$.

The total number of cotton seeds was significantly affected $(\mathrm{p}<0.01)$ by the irrigation with different $\mathrm{ECW}$ levels and, according to the regression equation (Figure $4 \mathrm{~A}$ ).
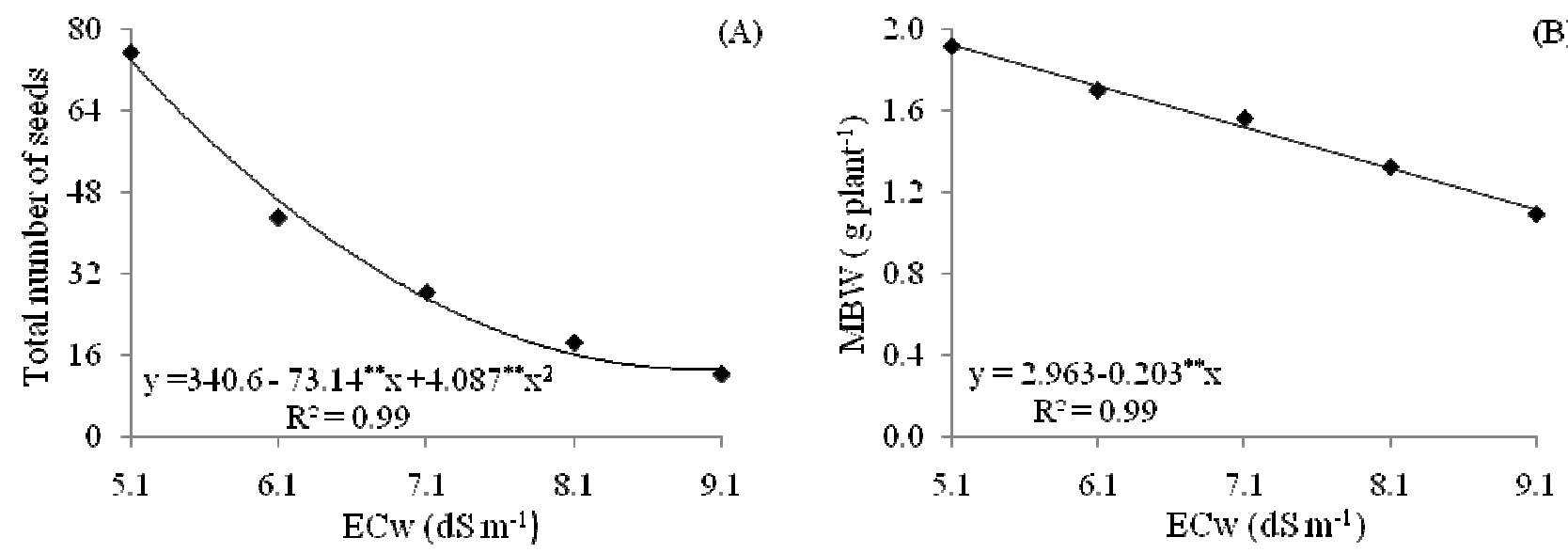

(B)

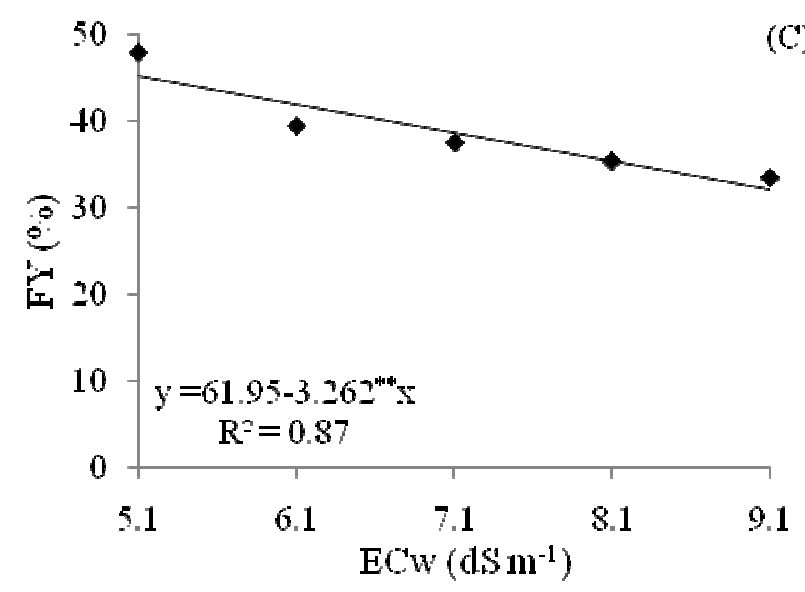

Figure 4. Total number of seeds - TNS (A), mean boll weight - MBW (B) and fiber yield - FY (C) of cotton, $\mathrm{cv}$. 'BRS Rubi', as a function of the electrical conductivity of the irrigation water - ECw, at 130 days after sowing.

The increase in irrigation water salinity caused a quadratic behavior, with highest value of
TNS (73.88 seeds) obtained in plants irrigated with $\mathrm{ECw}$ of $5.1 \mathrm{dS} \mathrm{m}^{-1}$ and, from this saline level on, 
Gas exchanges...

there was a reduction, with the lowest value (13.47 seeds) observed in cotton plants subjected to irrigation with $\mathrm{ECw}$ of $9.1 \mathrm{dS} \mathrm{\textrm {m } ^ { - 1 }}$. This harmful effect occurred because the increase in salinity, resulting from the application of the irrigation water, certainly decreased the osmotic potential of the soil solution, promoting increase in the tension necessary for the plant to absorb water from the soil, because its water potential becomes more negative. As a consequence, the plant had more difficulty using this water, which is not readily available, despite its presence in the soil (SOUSA et al., 2011), directly affecting the production of the cotton cultivar 'BRS Rubi'. In studies with the cotton cultivar 'Delta Opal', Oliveira et al. (2012) conducted experiment under greenhouse conditions (ECw: 0.5 to $6.5 \mathrm{dS} \mathrm{m}^{-1}$ ) and also observed quadratic behavior of $\mathrm{ECW}$ on the total number of seeds, reporting that the lowest value for this variable (6.53 seeds) was obtained at the highest water salinity level $\left(6.5 \mathrm{dS} \mathrm{m}^{-1}\right)$.

The different $\mathrm{ECw}$ levels negatively interfered with the mean boll weight of the cotton cultivar 'BRS Rubi'. According to the regression equation (Figure 4B), there was a decreasing linear effect, with reduction in MBW of the order of $6.85 \%$ per unit increase in irrigation water electrical conductivity, which corresponds to a reduction of $42.12 \%\left(0.81 \mathrm{~g} \mathrm{plant}^{-1}\right)$ in plants irrigated with ECw of $9.1 \mathrm{dS} \mathrm{m}^{-1}$, in relation to those under $5.1 \mathrm{dS} \mathrm{m}^{-1}$. Comparing the deleterious effects caused by irrigation water salinity on the studied production components, in relative terms, the TNS was the variable most affected by the increment in $\mathrm{ECW}$.

The fiber yield of the cotton cultivar 'BRS Rubi', according to the regression equation (Figure 4C), was linearly and negatively affected by the
LIMA, G. S. et al

levels of salinity of water $(\mathrm{p}<0.01)$, with reduction of $5.26 \%$ per unit increase in $\mathrm{ECw}$. The regression equation (Figure 4C) also indicates that cotton plants subjected to irrigation using water of highest ECw $\left(9.1 \mathrm{dS} \mathrm{m}^{-1}\right)$ exhibit a reduction of $28.10 \%$ in FY, compared with that under ECw level of $5.1 \mathrm{dS}$ $\mathrm{m}^{-1}$. Similar results were also reported by Oliveira et al. (2012), who studied the cotton cultivar 'Delta Opal' and observed that the higher the irrigation water salinity, the lower the yield in fibers.

\section{CONCLUSIONS}

The gas exchanges and production components of cotton, cv. 'BRS Rubi', are negatively affected by irrigation with saline waters with electrical conductivity higher than $5.1 \mathrm{dS} \mathrm{m}^{-1}$;

Among the studied variables, the $\mathrm{CO}_{2}$ assimilation rate and the total number of seeds per plant are the variables most sensitive to the effect of irrigation water salinity;

Nitrogen levels above $65 \mathrm{mg} \mathrm{kg}^{-1}$ of soil promoted decrease in the stomatal conductance of the cotton crop;

The interaction between the irrigation water salinity and the nitrogen doses did not influence any of the analyzed variables.

\section{ACKNOWLEDGMENTS}

To the National Program of Post-Doctorate (PNPD/CAPES/UFCG), for granting the scholarship to the first author and to the National Institute of Science and Technology in Salinity - INCTSal, for funding the project.

RESUMO: Conduziu-se esta pesquisa com o objetivo de avaliar, as trocas gasosas e os componentes de produção do algodoeiro de fibra colorida em função da irrigação com águas de diferentes níveis de salinidades e doses de nitrogênio. $\mathrm{O}$ experimento foi desenvolvido em lisímetros de drenagem, preenchidos com um Neossolo Regolítico Eutrófico de textura franco-arenosa, no município de Campina Grande, PB. O delineamento estatístico utilizado foi em blocos casualizados, cujos tratamentos resultaram da combinação de cinco níveis de condutividade elétrica da água de irrigação - CEa $\left(5,1 ; 6,1 ; 7,1 ; 8,1\right.$ e $\left.9,1 \mathrm{dS} \mathrm{m}^{-1}\right)$ e cinco doses de nitrogênio - DN $\left(65 ; 100 ; 135 ; 170 ; 205 \mathrm{mg} \mathrm{de} \mathrm{N} \mathrm{kg}^{-1}\right.$ de solo) em esquema fatorial 5x5, com três repetições. A interação entre os níveis salinos da água de irrigação e as doses de nitrogênio não influenciaram de forma significativa nenhuma das variáveis analisadas; as trocas gasosas e os componentes de produção do algodoeiro cv. BRS Rubi foram afetadas negativamente pela CEa superior a $5,1 \mathrm{dS} \mathrm{m}^{-1}$; a taxa de assimilação de $\mathrm{CO}_{2}$ e o número total de sementes por planta foram as variáveis mais sensíveis aos efeitos do estresse salino; doses de nitrogênio acima de $65 \mathrm{mg} \mathrm{kg}^{-1}$ promoveu diminuição na condutância estomática do algodoeiro.

PALAVRAS-CHAVE: Gossypium hirsutum L. BRS Rubi. Salinidade. Nitrogênio 


\section{REFERENCES}

ALBRECHT, L. P.; BRACCINI, A. de L.; ÁVILA, M. R.; BARBOSA, M. C.; RICCI, T. T.; ALBRECHT, A. J. P. Aplicação de biorregulador na produtividade do algodoeiro e qualidade de fibra. Scientia Agraria, Curitiba, v. 10, n. 3, p. 191-198, 2009. http://dx.doi.org/10.5380/rsa.v10i3.14474.

AYERS, R. S.; WESTCOT, D. W. A qualidade da água na agricultura. 2. ed. Campina Grande: UFPB. 1999.153p. Estudos FAO: Irrigação e Drenagem, 29.

BARHOUMI, Z., ATIA, A., RABHI, M., DJEBALL, W., ABDELLY, C., SMAOUI, A. Nitrogen and NaCl salinity effects on the growth and nutrient acquisition of the grasses Aeluropus littoralis, Catapodium rigidum, and Brachypodium distachyum. Journal of Plant Nutrition and Soil Science, Dubendorf, v. 173, n. 1, p. 149157, 2010. http://dx.doi.org/10.1002/jpln.200800113.

BEZERRA, A. K. P.; LACERDA, C. F. de; HERNANDEZ, F. F. F.; SILVA, F. B. da; GHEYI, H. R. Rotação cultural feijão caupi/milho utilizando-se águas de salinidades diferentes. Ciência Rural, Santa Maria, v. 40, n. 5, p. 1075-1082, 2010. http://dx.doi.org/10.1590/S0103-84782010000500012.

CAVAlCANTE, A. C. P.; DINIZ, B. L. M. T.; SILVA, A. G. da; DINIZ NETO, M. A.; OLIVEIRA, D. S. de; CAVALCANTE, A. P. Crescimento, produção e características tecnológicas da fibra de algodão colorido em diferentes coberturas no solo. Agropecuária Técnica, Areia, v. 36, n. 1, p. 240-247, 2015.

CLAESSEN, M. E. C. (org.). Manual de métodos de análise de solo. 2.ed. rev. atual. Rio de Janeiro: Embrapa CNPS, 1997. 212p. Documentos, 1.

DALlaGNOL, L. J.; RODRIGUES, F. A.; MARTINS, S. C. V.; CAVATTE, P. C.; DAMATTA, F. M. Alterations on rice leaf physiology during infection by Bipolarisoryzae. Australasian Plant Pathology, Dordrecht, v. 40, n. 4, p. 360-365, 2011. http://dx.doi.org/10.1007/s13313-011-0048-8.

EMBRAPA - Empresa Brasileira de Pesquisa Agropecuária. Centro Nacional de Pesquisa de Algodão. Algodão colorido: "Tecnologia Embrapa para a geração de emprego e renda na agricultura familiar do Brasil". Campina Grande: Embrapa CNPA, 2011. 2p. Circular Técnico, 17.

FERREIRA, D. F. Sisvar: A computer statistical analysis system. Ciência e Agrotecnologia, Lavras, v. 35, n. 6, p. 1039-1042, 2011. http://dx.doi.org/10.1590/S1413-70542011000600001.

FREIRE, J. L. O.; DIAS, T. J.; CAVALCANTE, L. F.; FERNANDES, P. D.; LIMA NETO, A. J. Rendimento quântico e trocas gasosas em maracujazeiro amarelo sob salinidade hídrica, biofertilização e coberturamorta. Revista Ciência Agronômica, Fortaleza, v. 45, n. 1, p. 82-91, 2014. http://dx.doi.org/10.1590/S180666902014000100011.

JERÔNIMO, J. F.; ALMEIDA, F. de A. C.;SILVA, O. R. R. F. da; BRANDÃO, Z. N.; SOFIATTI, V.; GOMES, J. P. Qualidade da semente e fibra de algodão na caracterização do descaroçador de 25 serras. Revista Brasileira de Engenharia Agrícola e Ambiental, Campina Grande, v. 18, n. 6, p. 64-671, 2014. http://dx.doi.org/10.1590/S1415-43662014000600015.

LIMA, G. S. de; NOBRE, R. G.; GHEYI, H. R.; SOARES, L. A. dos A.; SILVA, A. O. da. Crescimento e componentes de produçãoda mamoneira sob estresse salino e adubação nitrogenada. Engenharia Agrícola, Jaboticabal, v. 34, n. 5, p. 854-866, 2014. http://dx.doi.org/10.1590/S0100-69162014000500005.

LIMA, G. S. de; GHEYI, H. R.; NOBRE, R. G.; SOARES, L. A. dos A.; XAVIER, D. A.; SANTOS JÚNIOR, J. A. dos. Water relations and gas exchange in castor bean irrigated with saline water of distinct cationic nature. African Journal of Agricultural Research, Lagos, v. 10, n. 13, p. 1581-1594, 2015. http://dx.doi.org/10.5897/AJAR2015.9606. 
LIMA, G. S.; NOBRE, R. G.; GHEYI, H. R.; SOARES, L. A. A.; SILVA, A.O. Physiology, growth and yield of castor bean under salt stress and nitrogen dosesin phenophases. Idesia, Arica, v. 32, n. 3, p. 91-99, 2014. http://dx.doi.org/10.4067/S0718-34292014000300012.

MELO, A. S. de; SILVA JÚNIOR, C. D. da; FERNANDES, P. D.; SOBRAL , L. F.; BRITO, M. E. B.; DANTAS, J. D. M. Alterações das características fisiológicas da bananeira sob condições de fertirrigação. Ciência Rural, Santa Maria, v. 39, n. 3, p. 733-741, 2009. http://dx.doi.org/10.1590/S010384782008005000101.

MUNNS, R.; TESTER, M. Mechanism of salinity tolerance. Annual Review of Plant Biology, Palo Alto, v. 59, n. 1, p. 651-681, 2008. http://dx.doi.org/10.1146/annurev.arplant.59.032607.092911.

NEVES, A. L. R.; LACERDA, C. F. de; GUIMARÃES, F. V. A.; GOMES FILHO, E.; FEITOSA, D. R. C. Trocas gasosas e teores de minerais no feijão-de-corda irrigado com água salina em diferentes estádios. Revista Brasileira de Engenharia Agrícola e Ambiental, Campina Grande, v. 13, p. 873-881, 2009. http://dx.doi.org/10.1590/S1415-43662009000700009.

NOVAIS, R. F.; NEVES, J. C. L.; BARROS, N. F. Ensaio em ambiente controlado. In: OLIVEIRA, A. J. (ed.) Métodos de pesquisa em fertilidade do solo. Brasília: Embrapa SEA,1991. p. 189-25.

OLIVEIRA, F. de A. de; MEDEIROS, J. F. de; OLIVEIRA, F. R. A. de; FREIRE, A. G.; SOARES, L. C. da S. Produção do algodoeiro em função da salinidade e tratamento desementes com regulador de crescimento. Revista Ciência Agronômica, Fortaleza, v. 43, n. 2, p. 279-287, 2012. http://dx.doi.org/10.1590/S180666902012000200010.

RIBEIRO, R. V.; MACHADO, E. C.; SANTOS, M. G.;OLIVEIRA, R. F. Photosynthesis and water relations of well-watered orange plants as affected by winter and summer conditions. Photosynthetica, Prague, v. 47, n. 2 , p. 215-222, 2009. http://dx.doi.org/10.1007/s11099-009-0035-2.

RICHARDS, L. A. Diagnosis and improvement of saline and álcali soils. Washington: USDA, Department of Agriculture, 1954. 160p. Agriculture Handbook, n.60.

SHIMAZAKI, K.; DOI, M.; ASSMANN, S. M.; KINOSHITA, T. Light regulation of stomatal movement. Annual Review of Plant Biology, Palo Alto, v. 58, n. 6, p. 219-247,

2007.http://dx.doi.org/10.1146/annurev.arplant.57.032905.105434.

SHINOZAKI, K; YAMAGUCHI-SHINOZAKI, K. Gene networks involved in drought stress response and tolerance. Journal of Experimental Botany, Oxford, v. 58, n. 2, p. 221-227, 2007.

https://doi.org/10.1093/jxb/erl164.

SILVA, E. C.; NOGUEIRA, R. J. M. C.; ARAÚJO, F. P.; MELO, N. F.; AZEVEDO NETO, A.D. Physiological responses to salt stress in young umbu plants. Environmental and Experimental Botany, Oxford, v. 63, n. 1-3, p. 147-157, 2008. http://dx.doi.org/10.1016/j.envexpbot.2007.11.010.

SILVA, F. G.; DUTRA, W. F.; DUTRA, A. F.; OLIVEIRA, I. M.; FILGUEIRAS, L. M. B.;MELO, A. S. Trocas gasosas e fluorescência da clorofila em plantas de beringela sob lâmina de irrigação. Revista Brasileira de Engenharia Agrícola e Ambiental, Campina Grande, v.19, n.10, p.946-952, 2015. http://dx.doi.org/10.1590/1807-1929/agriambi.v19n10p946-952.

SOUSA, A . C.; LACERDA, C. F. de; GHEYI, H. R.; SOARES, F. A. L.; UYEDA, C. A. Teores de nutrientes foliares e respostas fisiológicas em pinhão manso submetido a estresse salino e adubação fosfatada. Revista Caatinga, Mossoró, v. 25, n. 2, p. 144-152, 2012. 
SOUSA, A. E. C.; GHEYI, H. R.; CORREIA, K. G.; SOARES, F. A. L.; NOBRE, R. G. Crescimento e consumo hídrico de pinhão manso sob estresse salino e doses de fósforo. Revista Ciência Agronômica, Fortaleza, v. 42, n. 2, p. 310-318, 2011. http://dx.doi.org/10.1590/S1806-66902011000200008.

SUASSUNA, J. F.; FERNANDES, P. D.; BRITO, K. S. A.; NASCIMENTO, R.; MELO, A. S.; BRITO, M. E. B. Trocas gasosas e componentes de crescimento em portaenxertos de citros submetidos à restrição hídrica. Irriga, Botucatu, v. 19, n. 3, p. 464-477, 2014. http://dx.doi.org/10.15809/irriga.2014v19n3p464.

TAIZ, L.; ZEIGER, E. Fisiologia vegetal. 4. ed. Porto Alegre, RS: Artmed, 2009. 819p.

WILLADINO, L.; CAMARA, T. R. Origen y naturaleza de los ambientes salinos. In: REIGOSA, M. J.; PEDROL, N.; SÁNCHEZ, A. (ed.). La ecofisiología vegetal - Uma ciencia de síntesis. Madrid: Thompson, 2004. p. 303 - 330. 